\title{
Bicycle Helmet Statutes: An Analysis of State Legislation
}

\section{John B. Egberts, Daniel P. Connaughton, and J.O. Spengler \\ University of Florida}

\begin{abstract}
Bicycling is a popular activity; however, like all physical activities, participants are exposed to some risk. While many bicycle-related injuries are not lifethreatening, head injuries are fairly common. A bicycle helmet is the single most effective method to reduce head injuries and related fatalities, however, overall use remains low. To address the lack of helmet use, especially among children, legislation has been implemented in a number of states. The purpose of this study was to analyze bicycle helmet statutes in states that had such legislation. A keyword search designed to identify bicycle helmet legislation for all 50 states was conducted by utilizing the LEXIS/NEXIS database. Statutes were analyzed and, based upon the information contained within, placed into a descriptive table by categories. Many of the statutes analyzed have similarities, however, notable differences exist. Comprehensive statutory information is provided in addition to a discussion of categorized results.
\end{abstract}

Bicycling is a popular recreational and sport activity in the United States, spanning all ages and skill levels. Each year, millions of Americans ride bicycles for exercise, commuting, recreation, and sport. The National Sporting Goods Association (NSGA, 2012) reported 39.1 million Americans over the age of six participated in bicycle riding during 2011. In addition, in 2011, nearly 16 million bicycles were sold in the U.S. with $\$ 6$ billion spent on bicycles, accessories, and parts (National Bicycle Dealers Association, 2012). Bicycling is an activity that is often recommended to address various health concerns and the overall decline in physical activity. To target such issues, the Safe Routes to School Program, which provides funding to encourage walking and bicycling to school, has apportioned over \$1.15 Billion since 2005 (National Center for Safe Routes to School, 2012).

Despite the popularity and benefits of bicycling, like all physical activity, participants are exposed to some risk. The National Highway Traffic Safety Administration (NHTSA) reported that, in 2010, 618 pedalcyclists were killed and another 52,000 injured in crashes involving motor vehicles (NHTSA, 2012). Further, the Consumer Product Safety Commission's (CPSC) National Electronic Injury Surveillance System (NEISS) estimated that over 541,000 bicycle-related injuries were treated in hospital emergency departments during 2010 (CPSC, 2011).

The authors are with the Dept. of Tourism, Recreation, and Sport Management, University of Florida, Gainesville, FL. 
Bicycling accounts for more injuries that are seen in emergency departments than any other sport or recreational activity. Of these emergency department visits, children 5-14 years old are treated at a rate more than four times those 25-64 years old (CPSC, 2011).

While many bicycle-related injuries are not life-threatening, head injuries are fairly common and among the most severe. For instance, between 1991-2005, roughly one-third of bicycle-related injuries resulting in hospitalization and $45 \%$ of fatalities were due primarily to head injury (Bicycle Helmet Research Foundation, n.d.). In addition to the number of bicycle fatalities stemming from head injuries, nonfatal traumatic brain injuries (TBI) occur more often and can result in long-term, negative health effects (e.g., memory loss, behavioral changes; Langlois, Rutland-Brown, \& Wald, 2006). Between 2001-2009, among persons 19 and under, there were 26,212 estimated annual bicycling-related TBIs seen in emergency departments, more than any other sport or recreational activity [Centers for Disease Control and Prevention (CDC), 2011].

Emergency department visits and hospitalizations due to head-related bicycling injuries are a substantial public health burden and responsible for considerable health care costs (Judy, 2011; Schulman, Sacks, \& Provenzano, 2002; Shah, Sinclair, Smith, \& Xiang, 2007). Specifically, head-related bicycling injuries and deaths account for an estimated $\$ 81$ million in direct and $\$ 2.3$ billion in indirect health costs annually (Schulman et al., 2002). Further, Shah et al. (2007) estimated $\$ 200$ million in inpatient costs for children in 2003, with an average of $\$ 18,654$ per hospitalization. While emergency department visits and inpatient care represent considerable costs, many individuals suffering from head-related bicycling injuries are also faced with a lifetime of treatment and related expenses (e.g., TBI). In an effort to reduce the occurrence and severity of head injuries and related fatalities among bicyclists, helmets are recommended by various organizations such as the American Academy of Orthopaedic Surgeons (2010), American Academy of Pediatrics (2001, 2007), Bicycle Helmet Safety Institute (BHSI, 2011), CDC (1995), CPSC (2012), League of American Bicyclists (LAB; 2005), NHTSA (2006), and Safe Kids USA (2009).

Bicycle helmets have evolved greatly over the last century with early models simply consisting of a few strips of leather sewn over minimal padding. In 1970, the Snell Foundation published the first voluntary bicycle helmet standard in the U.S. (BHSI, 2012a). In 1984, the American National Standards Institute (ANSI) also developed a voluntary bicycle helmet standard; however, in 1995 their standard expired and was declared obsolete. In the mid-1990s, the American Society for Testing and Materials (ASTM) replaced the Snell standard as the most used bicycle helmet standard. While this voluntary standard still exists today, it is seldom used (BHSI, 2012a).

The typical bicycle helmet, similar to those on the market today, emerged around 1990, and has expanded polystyrene (lightweight, strong foam) with a polycarbonate shell which protects the foam and lowers sliding resistance upon impact (BHSI, 2012a). Since 1999, all bicycle helmets produced for the U.S. market must meet the CPSC requirements for bicycle helmets published in the Code of Federal Regulations in Title 16, Part 1203 (CPSC, 2002). Any helmet that fails to meet these requirements is in violation of the Consumer Product Safety Act (2011). 
Helmets can help to reduce the risk of head and facial injuries by up to $88 \%$ and $65 \%$, respectively, making the use of helmets the single most effective method to reduce head and facial injuries and related fatalities from bicycle crashes (Thompson, Rivara, \& Thompson, 2009), which are consistent with findings of Persaud, Coleman, Zwolakowski, Lauwers, \& Cass (2012). Thus, increasing bicycle helmet use has been a primary goal for injury preven ${ }^{+i}$ on and safety advocates. While the effectiveness of bicycle helmets is clear, overall helmet use remains low (NHTSA, 2008). According to the national Youth Risk Behavior Survey, in 2011, nearly 88\% of high school students who had ridden a bicycle in the previous 12 months had rarely or never worn a helmet (CDC, 2012). Not surprisingly, approximately 85\% percent of bicyclists who died of bicycling crashes in 2010 were not wearing a helmet [Insurance Institute for Highway Safety (IIHS), 2012a].

To address the lack of helmet use, especially among children, legislation mandating helmet use has been implemented in a number of states and local municipalities throughout the U.S. Most of these laws target children under 16 years old, though some state and local laws require helmets for children under 18 years old (BHSI, 2012b). Rivara and Sattin (2011) noted that, from 1999-2007, the number and rate of bicycle-related deaths in the U.S. has decreased for those aged 16 years or less from $213(.31$ per 100,000$)$ to $118(.17$ per 100,000). While no state has a universal bicycle helmet law (i.e., required for all ages), all bicycle helmet laws cover minors (up to a certain age), which likely has contributed to the decrease in fatalities among those 16 years or less. Opponents to legislation mandating helmet use have claimed such laws reduce the amount of bicycling and therefore at least some of the reduction is attributable to reduced exposure (Carpenter \& Stehr, 2010; Robinson, 1996, 2007).

In the U.S., no federal legislation mandating bicycle helmet use currently exists. However, many municipalities have bicycle helmet laws. Thus, the purpose of this study was to analyze bicycle helmet statutes in all states that had such legislation.

\section{Methods}

To locate the bicycle helmet statutes, a search, of all 50 states and the District of Columbia, was conducted by keywords utilizing the LEXIS/NEXIS database. The keywords bicycle, pedalcycle, helmet, and bicycle helmet were used. The results of this search were cross referenced with bicycle helmet law data provided by the Bicycle Helmet Safety Institute (BHSI, 2012b), Insurance Institute for Highway Safety (2012b), and League of American Bicyclists (LABORATORY, 2012). The statutes were then analyzed and, based upon the information contained within, were placed into a descriptive table by categories. The categories included: state and citation, helmet law, effective date(s), age covered persons and activities covered, special requirements, helmet standards, sanctions for violations, and negligence. These major categories consistently appeared within the statutes and were also consistent with previously published information in this area (BHSI, 2012b; IIHS, 2012b; LABORATORY, 2012). A brief description of these categories follows.

The State and Citation category identifies each state and bicycle helmet statute citation if applicable. Helmet Law identifies whether there is a state or municipal (i.e., city, county) law. Effective Date(s) refers to the year the statute was enacted and when amended, if applicable. Age covered identifies the ages of individuals required by statue to wear a bicycle helmet. Persons and Activities Covered identifies 
bicyclists, bicycle passengers, bicycle trailers, and other sport/recreational activities that the statute covers. For example, in some states, bicycle helmet statutes require certain bicycle passengers to also wear a helmet, and that helmets must also be worn when participating in skateboarding, skating, sledding, toy vehicle, and/ or scooter activities. Special Requirements identifies whether the statute contains any specific requirements. For example, in some states it is required that a bicycle helmet be properly fitted and fastened. Helmet Standards identifies whether the state requires that bicycle helmets meet specific safety standards. For instance, some states require a helmet meet or exceed standards set by the ANSI, ASTM, Snell Memorial Foundation, and/or CPSC. Sanctions for Violations identifies potential penalties for violating the statutes. Negligence identifies if a statute mentions negligence, negligence per se, assumption of risk, and/or liability pertaining to not wearing a helmet when required by statute Negligence is a type of civil legal claim, synonymous with carelessness, brought where an injured party claims that a duty or responsibility owed by a defendant was breached, and the breach was the cause of injury or harm. To prove negligence, a plaintiff must show 1) that defendant owed plaintiff a duty, 2) that defendant breached that duty, 3) that this breach was the proximate cause of plaintiff's injury, and 4) that plaintiff suffered damages (Keeton, Dobbs, Keeton, \& Owen, 1984).

Two defenses to negligence that may be used in litigation involving a bicyclist who was injured are comparative and contributory negligence. Comparative negligence is a defensive scheme used by various states where damages are apportioned between the plaintiff and the defendant according to their degree of fault. Contributory negligence, in contrast, is a complete bar to recovery for an injured plaintiff, though it remains in only a few jurisdictions. In a contributory negligence jurisdiction, a negligent defendant can escape liability simply because the plaintiff was at fault in providing for his or her own safety (Cotten, 2010).

\section{Results}

Many of the statutes analyzed in this study have similarities. However, notable differences such as age and activities covered, helmet safety specifications, sanctions for violations, and defenses to negligence exist. General results of this study are discussed in the following sections, while comprehensive statutory information can be found in Online Appendix 1.

\section{Helmet Law}

Twenty-one states and the District of Columbia have state or district-wide bicycle helmet statutes. Sixteen states do not have a state law but have some municipal laws. Finally, 13 states have neither a state law nor any municipal bicycle helmet laws (BHSI, 2012b).

\section{Effective Date(s)}

California, in 1987, was the first state to enact a statewide bicycle helmet statute which required all bicycle passengers under five years old to wear a bicycle helmet. New York, Massachusetts, and Pennsylvania enacted legislation in 1989, 1990, and 
1991 respectively, with the same requirement. New Jersey, in 1992, was the first state to enact a bicycle helmet statute for both bicycle operators and passengers, requiring bicycle helmets for those under 14 years old whether operating or a passenger (N.J. Stat. Ann., 2012). Between 1992-1997, 13 other states enacted bicycle helmets laws for both operators and passengers. While the majority of state bicycle helmet statutes were enacted in the 1990s, New Mexico, in 2007, was the most recent state to enact such a law (N.M. Stat. Ann., 2012). In states that have a state law, the year the law was enacted or amended is provided in Online Appendix 1.

\section{Age Covered}

The earliest bicycle helmet laws only covered passengers under five years old. Of the 21 states and District of Columbia with bicycle helmet laws, 13 explicitly require bicycle helmets for bicycle operators and passengers under 16 years old. Three states (California, Delaware, and New Mexico) require helmets for bicycle operators and passengers under 18 years old. In addition, two states (New York and Massachusetts) prohibit bicycle passengers under the age of one year. No state requires bicycle helmet use for all ages.

\section{Persons and Activities Covered}

Twenty of the twenty-one states with laws, and the District of Columbia, require bicycle helmets for both bicycle operators and passengers. Connecticut's bicycle helmet statute covers bicycle operators, but does not explicitly mention passengers (Conn. Gen. Stat., 2012). Sixteen states with bicycle helmet laws require helmets for passengers specifically including those riding on a separate seat or in a bicycle trailer attachment. However, in Massachusetts the bicycle helmet statute does not apply to passengers if they are in an enclosed trailer or device which adequately protects the passenger's head in the event of a crash (Mass. Gen. Laws Ann., 2012). Four states (California, Maine, New Mexico, and Rhode Island) have helmet statutes which cover bicycling and other activities such as roller skating, skateboarding, and riding nonmotorized scooters. While other states have separate statutes requiring helmets for such activities, if they were not found in the state bicycle statutes, they were not included in this study.

\section{Special Requirements}

In addition to wearing a helmet, many states require helmets to be properly fitted and secured. Of the 21 states, and District of Columbia, with helmet laws, 18 specifically require helmets to have a good or proper fit and be fastened securely to the head. Of these 18, 14 require the helmet to be secured by the straps. For example, Florida's statute requires that anyone under the age of 16 years old must wear a helmet that is properly fitted and is fastened securely upon the head by a strap (Fla. Stat., 2012). Four states (Connecticut, Maryland, New Hampshire, and Oregon) have no special requirements with regard to helmet fit or securing.

\section{Helmet Standards}

While all bicycle helmets produced and sold in the U.S. must meet the CPSC standard (CPSC, 2002), only eight states explicitly reference this standard in their 
bicycle helmet statute. Fourteen states and the District of Columbia reference the American National Standards Institute (ANSI) bicycle helmet standards, while 15 reference the Snell Memorial Foundation's bicycle helmet standards. Seven states and the District of Columbia reference the ASTM bicycle helmet standards, while eight states reference other standards or requirements. For example, Hawaii requires bicycle helmets to be tested by nationally recognized agencies such as the NHTSA, National Safety Council, or Children's Safety Network (Hawaii Rev. Stat., 2012). It is important to note that most states and the District of Columbia reference more than one bicycle helmet safety standard. For example, Florida references bicycle helmet safety standards from the Snell Memorial Foundation, ANSI, or any other nationally recognized standards adopted by the state (Fla. Stat., 2012).

\section{Sanctions for Violations}

Sanctions for violating bicycle helmet statutes vary among the states and the District of Columbia. Sanctions range from no civil penalties and court costs (La. R.S., 2012) to up to $\$ 100$ for second and subsequent offenses (N.J. Stat. Ann., 2012). Thirteen states make it unlawful for a parent or legal guardian to permit their child to operate or be a passenger on a bicycle without wearing a helmet, and in some cases, hold them either jointly and severally liable or completely liable for fines and/or punishment. For example, in West Virginia, a parent who violates a bicycle helmet statutory requirement may be fined $\$ 10$ and/or required to complete two hours of community service related to child injury prevention (W. Va. Code, 2012). However, eleven states have provisions to dismiss fines and punishments if proof of helmet ownership can be shown. Sanctions, in Delaware or Oregon, will not be levied for those who choose not to wear bicycle helmets in accordance with religious practices.

\section{Negligence}

Nine states (Connecticut, Delaware, Florida, Georgia, Louisiana, New York, Massachusetts, Pennsylvania, and Rhode Island) have laws that address noncompliance with statutory helmet requirements in the context of negligence. In four states (Connecticut, Delaware, Pennsylvania, and Rhode Island), evidence of a violation of the statute (e.g., failure to wear a required and properly secured helmet) would not be admissible in a negligence lawsuit. For example, Rhode Island law states "... nor shall the failure to wear a helmet be admissible as evidence in the trial of any civil action" (R.I. Gen. Laws, 2012). Suppose, for example, that a bicyclist who was not wearing a helmet while traveling in a designated bike lane was struck by a driver who veered into the bike lane. The fact that the bicyclist was not wearing a helmet could not be used against them to demonstrate comparative or contributory fault in a state with a law precluding the admissibility of such evidence. Eight of the above mentioned states indicate that a failure to wear a helmet would not constitute comparative or contributory negligence. Delaware legislation provides that

Failure to wear a bicycle helmet as herein described shall not be considered evidence of either comparative or contributory negligence in any civil suit arising out of any accident in which a person under 18 years of age is injured .... (Del. C., 2012) 
Further, Georgia law states that a violation of the helmet law "shall not constitute negligence per se nor contributory negligence per se or be considered evidence of negligence or liability" (Ga. Code Ann., 2012). However, Louisiana states in their law that where there is a violation of the helmet law, "The comparative negligence statutes of Louisiana shall apply in these cases as in all other cases of negligence" (La. R.S., 2012). Other states may also have provisions that prevent the legal lack of helmet use from being used against an injured bicyclist to show contributory or comparative negligence or to reduce damage awards, however, they are often found in code sections addressing negligence or rules of evidence (Mionske, 2007).

\section{Discussion}

Previous research has shown bicycle helmet laws increase the rate of helmet usage among target populations (Delamater \& Patino, 2003; Kanny, Schieber, Pryor, \& Kresnow, 2001; Karkhaneh, Kalenga, Hagel, \& Rowe, 2006; Liller et al., 2003; Rodgers, 2002; Wesson et al., 2008). A systematic review examining the effectiveness of helmet legislation in the U.S., Canada, Australia, and New Zealand reported increases in helmet usage from baselines of $4 \%$ and $59 \%$ to $47 \%$ and $91 \%$, respectively (Karkhaneh et al., 2006). Similarly, Macpherson and Spinks (2008) conducted a Cochrane systematic review and reported "bicycle helmet legislation appears to be effective in increasing helmet use and decreasing head injury rates in populations for which it is implemented" (p. 2). Resonating with Macpherson and Spinks (2008), bicycle helmet legislation has not only been shown to increase helmet usage, but also decrease head injuries and fatalities (Grant \& Rutner, 2004; Liller et al., 2003). Grant and Rutner (2004) reported a $15 \%$ reduction of fatalities due to bicycle helmet legislation and estimated "if all states had adopted helmet laws in 1975, more than 1,500 lives would have been saved" (p. 595).

Helmet legislation is an effective method to increase helmet use, especially when accompanied by law enforcement (Coté et al., 1992; Gilchrist, Schieber, Leadbetter, \& Davidson, 2000; Ni, Sacks, Curtis, Cieslak, \& Hedberg 1997; Puder, Visintainer, Spitzer, \& Casal, 1999). Interestingly, results of the current study revealed that sanctions for violating bicycle helmet laws ranged from no civil penalties and court costs (La. R.S., 2012) to up to $\$ 100$ for second and subsequent offenses (N.J. Stat. Ann., 2012). Thirteen states (59\%) make it unlawful for a parent or legal guardian to permit their child to operate or be a passenger on a bicycle without wearing a helmet, and in some cases, hold them either jointly and severally liable or completely responsible for fines (e.g., in New Mexico and North Carolina, up to $\$ 10$; in New Jersey, up to $\$ 100$ ) or punishment (e.g., in West Virginia, two hours of community service related to a child injury prevention program).

Where legislation has been enacted, educational and outreach programs have helped sustain helmet use rates (Coté et al., 1992; Liller et al., 2003; Ni et al., 1997; Rodgers, 2002). Another potentially effective method of increasing youth helmet use occurs when children bicycle with a helmeted adult. Khambalia, MacArthur and Parkin (2005) found that $95 \%$ of children bicycling with a helmeted adult wore helmets, compared with $41 \%$ of children bicycling with a nonhelmeted adult. Parent, teachers, helmet advocates and others should take advantage of such role modeling behavior. While legislation, enforcement, education, and role modeling are likely to increase helmet use among youth, proper usage and fit is another 
concern. Rivara, Astley, Clarren, Thompson, and Thompson (1999) noted the high incidence of improper helmet fit among bicyclists suffering a head injury. In addition, Parkinson and Hike (2003) found, despite relatively high levels of helmet use, $96 \%$ of children wore helmets that were of inadequate condition and/or not properly fitted. The results of the current study revealed that of the 21 states, and District of Columbia, with helmet laws, $18(82 \%)$ specifically require helmets to have a good or proper fit and be fastened securely to the head. Of these 18 states, $14(78 \%)$ require the helmet to be secured by the straps.

The results of the current study indicate that nine states (Connecticut, Delaware, Florida, Georgia, Louisiana, New York, Massachusetts, Pennsylvania, and Rhode Island) address noncompliance with statutory helmet requirements in the context of civil lawsuits for negligence. Eight of these states (Connecticut, Delaware, Florida, Georgia, New York, Massachusetts, Pennsylvania, and Rhode Island) had legislation that sought to protect the right to compensation for injury of a child or youth, or parent or legal guardian of a child, who failed to meet the helmet requirements of the statute. This was addressed in the legislation by either 1) not allowing evidence of a violation of the statute (e.g., requiring helmet use) to be admissible in court, 2) not allowing a violation of the statute to constitute negligence per se, or 3) not allowing a violation of the statute to be considered contributory or comparative negligence on the part of an injured bicyclist. If the actions of a person violate a statute, they are often considered to be negligent under the doctrine of negligence per se. Therefore, if a child were injured while not wearing a helmet in violation of a statute, it could be argued that their fault (negligence) would negate the responsibility of a defendant to compensate them for their injuries.

Comparative and contributory negligence in the context of the statutes identified in this study, represent a defense to negligence available to a defendant whereby some degree of fault and subsequent monetary damages are shifted away from the defendant. In a pure comparative negligence jurisdiction, for example, the defendant is only liable for the proportion of fault attributed to their own carelessness. If an injured bicyclist were in violation of the statute for not wearing a helmet, in the absence of language in the statute negating comparative or contributory negligence, their ability to be compensated for their injuries could be reduced or eliminated.

While 21 states, and the District of Columbia, had bicycle helmet statutes at the time this study was conducted, this area is rapidly changing. For example, as of October 7, 2012, using GovTrack.us, a search of "bicycle helmet" within state legislatures revealed six states that had current bills involving bicycle helmets. In addition, some jurisdictions are, and others may consider, repealing bicycle helmet laws. For example, on June 1, 2012, the town of Milton, Washington repealed a bicycling and skateboarding helmet law that had been in effect for 15 years. According to Johnson (2012), the decision was made because their 12-member police force was stressed due to an increasing number of crimes and a decreasing budget. Milton's insurance consultant argued that their inability to enforce the bicycle helmet law created potential liability in the event a bicyclist, that was not warned and/or cited for lack of helmet use, was injured and sued (Johnson, 2012). While this example involves a municipality, states may also face these issues and dilemmas. In addition to these evolving statutes, the subject of mandatory bicycle helmet laws will likely remain controversial (de Jong, 2012). The debate over whether such legislation ultimately reduces the number of bicyclists, who could be missing the benefits of physical 
exercise and reducing the amount motor vehicle traffic, is one worthy of future research. Additional related research may also include: an analysis of municipal or international bicycle helmet statutes; a study of law enforcement officers' attitudes and beliefs regarding bicycle helmet statute enforcement; and a study comparing helmet usage in similar jurisdictions with and without helmet legislation.

\section{References}

Ala. Code $\S \S 32-5 A-281-285$ (2012).

American Academy of Orthopaedic Surgeons. (2010). Helmet use by motorcycle drivers and passengers, and bicyclists. Retrieved from http://www.aaos.org/about/papers/ position/1110.asp

American Academy of Pediatrics. (2001). Policy statement: Bicycle helmets. American Academy of Pediatrics, 108, 1030-1032.

American Academy of Pediatrics. (2007). AAP publications retired or reaffirmed, October 2006. American Academy of Pediatrics, 119, 405.

Bicycle Helmet Research Foundation. (n.d.). NEISS data on bicyclist injuries. Retrieved from http://www.cyclehelmets.org/1177.html

Bicycle Helmet Safety Institute. (2011). Should I wear a helmet? Retrieved from http:// www.helmets.org/shouldi.htm

Bicycle Helmet Safety Institute. (2012a). Bicycle helmet standards. Retrieved from http:// bhsi.org/standard.htm

Bicycle Helmet Safety Institute. (2012b). Helmet laws for bicycle riders. Retrieved from http://www.helmets.org/mandator.htm

Cal Veh. Code $\$ 21212$ (2012).

Carpenter, C.S., \& Stehr, M.F. (2010, January). Intended and unintended effects of youth bicycle helmet laws. National Bureau of Economic Research (Working Paper No. 15658). Cambridge, MA: NBER.

Centers for Disease Control and Prevention. (1995). Injury-control recommendations: bicycle helmets. Morbidity and Mortality Weekly Report: Recommendations and Reports, 44(RR-1), 1-18.

Centers for Disease Control and Prevention. (2011). Nonfatal traumatic brain injuries related to sports and recreation activities among persons aged $\leq 19$ - United States, 2001-2009. Morbidity and Mortality Weekly Report, 60(39), 1337-1342.

Centers for Disease Control and Prevention. (2012). Youth risk behavior surveillance - United States, 2011. MMWR. Surveillance Summaries, 61(4), 1-162.

Conn. Gen. Stat. § 14-286d (2012).

Consumer Product Safety Act. (2011). 15 U.S.C. §§ 2051-2089.

Consumer Product Safety Commission. (2002). Requirements for bicycle helmets: 16 C.F.R. Part 1203. Retrieved from http://www.cpsc.gov/businfo/regsumbicyclehelmets.pdf

Consumer Product Safety Commission. (2011). NEISS highlights - 2010. Retrieved from http://www.cpsc.gov/neiss/2010highlights.pdf

Consumer Product Safety Commission. (2012). CPSC safety alert: CPSC urges bicyclists to wear helmets. Retrieved from www.cpsc.gov/cpscpub/pubs/5002.pdf

Coté, T.R., Sacks, J.J., Kresnow, M., Lambert-Huber, D.A., Schmidt, E.R., Dannenberg, A.L., \& Lipsitz, C.M. (1992). Bicycle helmet use among Maryland children: Effect of legislation and education. Pediatrics, 89, 1216-1220.

Cotten, D.J. (2010). Defenses against negligence. In D.J. Cotten \& J.T. Wolohan (Eds.), Law for recreation and sport managers (5th ed., pp. 66-79). Dubuque, IA: Kendall/Hunt.

D.C. Code $\S \S 50-1605,50-1609$ (2012).

de Jong, P. (2012). The health impact of mandatory bicycle helmet laws. Risk Analysis, 32(5), 782-790. doi:10.1111/j.1539-6924.2011.01785.x 
Del. C. $21 \S 4198 K(2012)$.

Delamater, A.M., \& Patino, A.M. (2003). Bicycle helmet wearing in children: a seven-year, observational study in Broward County, FL. Children's Health Care, 32(4), 287-295. doi:10.1207/S15326888CHC3204_4

Fla. Stat. § 316.2065 (2012).

Ga. Code Ann. § 40-6-296 (2012).

Gilchrist, J., Schieber, R., Leadbetter, S., \& Davidson, S. (2000). Police enforcement as part of a comprehensive. Pediatrics, 106(1), 6-9. doi:10.1542/peds.106.1.6

Grant, D., \& Rutner, S.M. (2004). The effect of bicycle helmet legislation on bicycling fatalities. Journal of Policy Analysis and Management, 23(3), 595-611. doi:10.1002/ pam.20029

Hawaii Rev. Stat. § 291C-150 (2012).

Insurance Institute for Highway Safety. (2012a). Fatality facts 2010: Bicycles. Retrieved from http://www.iihs.org/research/fatality.aspx?topicName=Bicycles\&year=2010

Insurance Institute for Highway Safety. (2012b). Motorcycle and bicycle helmet use laws. Retrieved from http://www.iihs.org/laws/HelmetUseCurrent.aspx

Johnson, K. (2012, June 18). Dropping helmet laws to reduce a town's risk. New York Times. Retrieved from http://www.nytimes.com/2012/06/19/us/to-avert-liability-washingtontown-drops-helmet-laws.html?_r=2\&

Judy, K. (2011).Unintentional injuries in pediatrics. Pediatrics in Review, 32(10), 431-438.

Kanny, D., Schieber, R.A., Pryor, V., \& Kresnow, M. (2001). Effectiveness of a state law mandating use of bicycle helmets among children: An observational evaluation. American Journal of Epidemiology, 154(11), 1072-1076. doi:10.1093/aje/154.11.1072

Karkhaneh, M., Kalenga, J-C., Hagel, B.E., \& Rowe, B.H. (2006). Effectiveness of bicycle helmet legislation to increase helmet use: A systematic review. Injury Prevention, 12, 76-82. doi:10.1136/ip.2005.010942

Keeton, W.P., Dobbs, D.B., Keeton, R.E., \& Owen, D.G. (1984). Prosser and Keeton on torts (5th ed.). St. Paul, MN: West.

Khambalia, A., MacArthur, C., \& Parkin, P.C. (2005). Peer and adult companion helmet use is associated with bicycle helmet use by children. Pediatrics, 116, 939-942. doi:10.1542/peds.2005-0518

Langlois, J.A., Rutland-Brown, W., \& Wald, M.M. (2006). The epidemiology and impact of traumatic brain injury. The Journal of Head Trauma Rehabilitation, 21, 375-378. doi:10.1097/00001199-200609000-00001

La. R.S. 32:199 (2012).

League of American Bicyclists. (2005). Helmet use when cycling. Retrieved from http:// www.bikeleague.org/about/positions/helmetuse.php

League of American Bicyclists. (2012). State bike laws center. Retrieved from http://www. bikeleague.org/action/bikelaws/state_laws.php

Liller, K.D., Nearns, J., Cabrera, M., Joly, B., Noland, V., \& McDermott, R. (2003). Children's bicycle helmet use and injuries in Hillsborough County, Florida before and after helmet legislation. Injury Prevention, 9, 177-179. doi:10.1136/ip.9.2.177

Macpherson, A., \& Spinks, A. (2008). Bicycle helmet legislation for the uptake of helmet use and prevention of head injuries. Cochrane Database of Systematic Reviews, 3, 1-15.

Mass. Gen. Laws Ann. ch. 85, §§ 11B, 11B1/2 (2012).

Md. Transportation Code Ann. $\S \S 21-1207.1,21-1207.2$ (2012).

Me. Rev. Stat. Ann. 29 M.R.S. §§ 2322, 2323, 2326 (2011).

Mionske, B. (2007). Bicycling and the law. Boulder, CO: Velo Press.

National Bicycle Dealers Association. (2012). 2011 NBDA statpak: A look at the bicycle industry's vital statistics. Retrieved from http://nbda.com/articles/industry-overview2011-pg34.htm

National Center for Safe Routes to School. (2012). State apportionments. Retrieved from http://apps.saferoutesinfo.org/legislation_funding/state_apportionment.cfm\#table 
National Highway Traffic Safety Administration. (2006). Easy steps to properly fit a bicycle helmet. Retrieved from http://www.nhtsa.gov/people/injury/pedbimot/bike/ easystepsweb/

National Highway Traffic Safety Administration. (2008). Traffic safety facts: Laws, bicycle helmet use laws. Washington, DC: NHTSA.

National Highway Traffic Safety Administration. (2012). Traffic safety facts: 2010 data, bicyclist and other cyclists. Washington, DC: NHTSA.

National Sporting Goods Association. (2012). 2011 Sports participation - Ranked by total participation. Retrieved from http://www.nsga.org/i4a/pages/index.cfm?pageid=3346

N.C. Gen. Stat. §§ 20-171.7, 20-171.8, 20-171.9 (2012).

N.H. Rev. (2012). Stat. Ann., 265, 144.

Ni, H., Sacks, J.J., Curtis, L., Cieslak, P.R., \& Hedberg, K.H. (1997). Evaluation of a statewide bicycle helmet law via multiple measures of helmet use. Archives of Pediatrics \& Adolescent Medicine, 151(1), 59-65. doi:10.1001/archpedi.1997.02170380063010

N.J. Stat. Ann. §§ 39:4-10.1, 4-10.2, 4-10.5, 4-10.6 (2012).

N.M. Stat. Ann. §§ 32A-24-2, 32A-24-3 (2012).

N.Y. CLS Veh \& Tr $§ 1238$ (2012).

Or. Rev. Stat. $\S \S 814.484,814.485,814.487,814.488,814.489,814.600,815.052$ (2011).

Parkinson, G.W., \& Hike, K.E. (2003). Bicycle helmet assessment during well visits reveals severe shortcomings in condition and fit. Pediatrics, 112, 320-323. doi:10.1542/ peds.112.2.320

75 Pa. Cons. Stat. $§ 3510$ (2012).

Persaud, N., Coleman, E., Zwolakowski, D., Lauwers, B., \& Cass, D. (2012). Nonuse of bicycle helmets and risk of fatal head injury: a proportional mortality, case-control study. Canadian Medical Association Journal, 184(17), 921-923. doi:10.1503/cmaj.120988

Puder, D.R., Visintainer, P., Spitzer, D., \& Casal, D. (1999). A comparison of the effect of different bicycle helmet laws in 3 New York City suburbs. American Journal of Public Health, 89(11), 1736-1738. doi:10.2105/AJPH.89.11.1736

R.I. Gen. Laws § 31-19-2.1 (2012).

Rivara, F.P., Astley, S.J., Clarren, S.K., Thompson, D.C., \& Thompson, R.S. (1999). Fit of bicycle safety helmets and risk of head injuries in children. Injury Prevention, 5 , 194-197. doi:10.1136/ip.5.3.194

Rivara, F., \& Sattin, R.W. (2011). Preventing bicycle-related injuries: Next steps. Injury Prevention, 17(3), 215. doi:10.1136/injuryprev-2011-040046

Robinson, D.L. (1996). Head injuries and bicycle helmet laws. Accident; Analysis and Prevention, 28, 463-475. doi:10.1016/0001-4575(96)00016-4

Robinson, D.L. (2007). Bicycle helmet legislation: can we reach a consensus? Accident; Analysis and Prevention, 39, 86-93. doi:10.1016/j.aap.2006.06.007

Rodgers, G.B. (2002). Effects of state helmet laws on bicycle helmet use by children and adolescents. Injury Prevention, 8, 42-46. doi:10.1136/ip.8.1.42

Safe Kids, U.S.A. (2009). Bicycling and skating tips. Retrieved from http://www.safekids. org/safety-basics/safety-resources-by-risk-area/bicycling-and-skating/bicycling-andskating-safety.html

Schulman, J., Sacks, J., \& Provenzano, J. (2002). State level estimates of the incidence and economic burden of head injuries stemming from non-universal use of bicycle helmets. Injury Prevention, 8, 47-52. doi:10.1136/ip.8.1.47

Shah, S., Sinclair, S.A., Smith, G.A., \& Xiang, H. (2007). Pediatric hospitalizations for bicycle related injuries. Injury Prevention, 13, 316-321. doi:10.1136/ip.2007.016048

Tenn. Code Ann. §§ 55-52-103, 55-52-105, 55-52-106 (2012).

Thompson, D.C., Rivara, F., \& Thompson, R. (2009). Helmets for preventing head and facial injuries in bicyclists (Review). Cochrane Database of Systematic Reviews, 1, 1-31.

W. Va. Code $\S \S 17$ C-11A-3, 11C-11A-4, 17C-11A-7 (2012).

Wesson, D.E., Stephens, D., Lam, K., Parsons, D., Spence, L., \& Parkin, P.C. (2008). Trends in pediatric and adult bicycling deaths before and after passage of a bicycle helmet law. Pediatrics, 122(3), 605-610. doi:10.1542/peds.2007-1776 